\title{
Carbon and phosphorus biogeochemical cycles in native forest and horticultural areas in the Metropolitan Region of Curitiba, Brazil
}

Tatiana Suzin Lazeris, Jéssica Pereira de Souza, Fabiane Machado Vezzani, Caroline Lima de Matos, Glaciela Kaschuk

Universidade federal do Paraná - UFPR, PR. E-mail: glaciela.kaschuk@ufpr.br

\begin{abstract}
This study was carried out to understand the dynamics of carbon and phosphorus biogeochemical cycles in native forest and horticultural areas. Soil samples were collected from native forest and horticultural areas, in four municipalities in the Metropolitan Region of Curitiba, Brazil, and evaluated for: carbon, nitrogen and phosphorus of soil microbial biomass (MBC, MBN and MBP, respectively), total organic carbon (TOC), total nitrogen (TN), total phosphorus (TP), inorganic phosphorus (iP), organic phosphorus (OP) and available phosphorus (aP. Soil suspensions diluted at $10^{-4}$ were spread on plates and phosphate solubilizing bacteria (PSB) were counted. The analyses showed that horticultural areas soils accumulated $43 \%$ more TP whereas they lost $23 \%$ of TOC and $19 \%$ of TN comparing to native areas. $69 \%$ of TP in the native areas was organic (OP) whereas $59 \%$ of TP in the horticultural areas was inorganic (iP). Horticultural areas had lower numbers of colony forming unities of PSB than native areas. PSB was positively correlated with the ratio of MBC to TOC (qMic), which in turn, was negatively correlated with TOC and TN. Changes in the soil P fractions suggested a shift in the soil community bacterial structure and in the values of soil microbial biomass of the two different soil ecosystems. The excessive $P$ addition may stimulate soil microbial attack to soil organic matter reserves, which may have consequences for maintenance of soil quality and agriculture sustainability.
\end{abstract}

Keywords: P solubilizing bacteria; soil intensive use; soil organic matter; vegetables production.

Ciclos biogeoquímicos de carbono e fósforo em áreas de floresta nativa e horticultura na Região Metropolitana de Curitiba, Brasil

\section{Resumo}

Este estudo foi realizado com o objetivo de compreender a dinâmica dos ciclos biogeoquímicos do carbono e do fósforo em áreas de floresta nativa e horticultura. Amostras de solo foram coletadas em áreas de floresta nativa e horticultura, em quatro municípios da Região Metropolitana de Curitiba, Brasil, e avaliadas quanto a: carbono, nitrogênio e fósforo da biomassa microbiana ( $M B C, M B N$ e $M B P$, respectivamente), carbono orgânico total (TOC), nitrogênio total (TN), fósforo total (TP), fósforo inorgânico (iP), fósforo orgânico (oP) e fósforo disponível (aP). As suspensões de solo foram diluídas até $10^{-4}$ e espalhadas em placas de Petri, e, as bactérias solubilizadoras de fosfato (PSB) foram contadas. As análises mostraram que os solos das áreas de horticultura acumularam $43 \%$ a mais de TP enquanto perderam $23 \%$ de TOC e $19 \%$ de TN, em comparação com as áreas nativas. $69 \%$ do TP nas áreas nativas era orgânico (oP) enquanto 59\% do TP nas áreas de horticultura era inorgânico (iP). As áreas de horticultura apresentaram menor número de unidades formadoras de colônias de PSB do que as áreas nativas. PSB foi positivamente correlacionado com a razão de MBC para TOC (qMic), que por sua vez, foi negativamente correlacionado com TOC e TN. Mudanças nas frações de $P$ do solo podem ter levado a uma mudança na estrutura bacteriana da comunidade do solo e nos valores de biomassa microbiana do solo. A adição excessiva de $P$ pode estimular o ataque microbiano do solo às reservas de matéria orgânica do solo, o que pode ter consequências para a manutenção da qualidade do solo e sustentabilidade da agricultura.

Palavras-chave: bactérias solubilizadoras de P; uso intensivo do solo; matéria orgânica do solo; produção de hortaliças. 


\section{Introduction}

Phosphate is one of the major nutrients required by living organisms, but its availability is limited in tropical and subtropical soils around the world. The availability of $P$ in soil solution results from the process of solubilization from minerals and mineralization of soil organic matter in the $P$ biogeochemical cycle (EHLERS et al., 2010; HARTMAN; RICHARDSON, 2013; HEUCK et al., 2015; SPOHN; CHODAK, 2015; LI et al., 2015). The concentration of available $P$ in the soil solution is usually low because the ion $\mathrm{PO}_{4}^{-}$is highly attracted by mineral surfaces, and because soil microrganisms and plants compete for the same pool in the absorption process (EHLERS et al., 2010; HARTMAN; RICHARDSON, 2013; HEUCK et al., 2015; SPOHN; CHODAK, 2015; Ll et al., 2015).

Plants may deal with $P$ limitation by releasing organic acids in the rhizosphere to solubilize inorganic $P$ (HOFFLAND et al., 1989), by increasing the production and release of phosphatase that breakdown organic $P$ (YUN; KAEPPLER, 2001), by increasing root extension and architecture (NIU et al., 2013), by stablishing partnership with mycorrhizal fungi (SMITH et al., 2011) and other plant growth promoting microrganisms (KAFLE et al., 2019). Despite the strong binding of $P$ in solid soil particles, soil microorganisms may increase $P$ availability in the soil because they release organic acids and protons that decrease soil $\mathrm{pH}$ and weaken chemical bonds between $\mathrm{H}_{2} \mathrm{PO}_{4}^{-}$and $-\mathrm{FeOH}$ and AIOH (RICHARDSON, 2001; RICHARDSON; SIMPSON, 2011; GLICK, 2012; SHARMA et al., 2013; ZHU et al., 2018; YAO et al., 2018). The P absorbed by roots and microorganisms is incorporated into organic $\mathrm{P}(\mathrm{OP})$. Organic $\mathrm{P}$ represents $5-80 \%$ of total $P$ in the soil (TP) (BROOKES et al., 1982) and can be mineralized and recycled through enzymatic (phosphatase) activity (RICHARDSON; SIMPSON, 2011; SHARMA et al., 2013). On one hand, soil microbial growth is coupled with mineralization of $\mathrm{P}$ and it may be one of the major process that makes $P$ available for root uptake (GERKE, 2015). On the other hand, microbial growth in soil increases the immobilization of $P$, by increasing microbial biomass $\mathrm{P}(\mathrm{MBP})$, even though immobilization is a transient inconvenient because $\mathrm{P}$ may become available again after the microorganisms death (BROOKES et al., 1982; BALOTA et al., 2003).

The soil microbial biomass, considered as the living fraction of soil organic matter, composed of bacteria, archaea, fungi, algae, protozoa and other organisms smaller than $5 \times 10^{3} \mu^{3}$, is also limited by other nutrients (e.g. carbon, nitrogen, sulfur) because the nutrients cycling processes are coupled with the process of soil organic matter decomposition. The soil microbial biomass represents 2 to $5 \%$ of total organic carbon (TOC), 1 to $5 \%$ of total nitrogen (TN) and 5 to $80 \%$ of total P (TP) depending on the soil conditions (VANCE et al., 1987; BROOKES et al., 1982; BROOKES et al., 1985). It is expected that the maximum growth of soil microbial biomass is determined by the nutrient that is less available in the soil solution (HARTMAN; RICHARDSON, 2013; HEUCK et al., 2015; SPOHN; CHODAK, 2015; LI et al., 2015; YAO et al., 2018). Therefore, although it is emphasized that TOC and TN are limiting factors for the soil microbiota growth (SPOHN; CHODAK, 2015), the total P (TP) is also crucial (LI et al., 2015; YAO et al., 2018).

The Metropolitan Region of Curitiba is composed by 29 municipalities (over 3.5 million inhabitants) and occupies $16,581 \mathrm{~km}^{2}$, being $44 \%$ with small-sized farms ( $<3.5 \mathrm{ha}$ ) managed by familiar farming (IPARDES, 2004) that, in 2016, produced 1,196,593 tons of vegetables (SEAB, 2016). The horticultural production systems have operated within urban, peri-urban, and legal units of biodiversity conservation, with intense soil preparation that increases the risks of erosion and pollution by eutrophization (RAMOS et al., 2014). Since vegetables are fast-growing crops and have a high demand for nutrients, farmers commonly apply high doses of fertilizers and external organic waste (e.g. poultry litter) whose excess is accumulated in the soil (RAMOS et al,. 2014). Therefore, while $\mathrm{P}$ limitation is an issue over the world, in metropolitan regions like the Metropolitan Region of Curitiba, excessive $P$ addition may become a potential environmental issue. Intensive agriculture may result in soil erosion (RAMOS et al., 2014), and, an hypothesis is that excessive $\mathrm{P}$ addition may stimulate soil microbial attack to soil organic matter reserves, which, may have consequences for maintenance of soil quality and agriculture sustainability.

Considering that the nutrients biogeochemical cycle are interconnected within several processes and that the soil microbial biomass may influence the $P$ biogeochemical cycle but may be affected by $P$ availability as well, this study was conducted to verify whether changes in soil $P$ fractions from native forest areas to 
horticultural areas may affect the nutrient fractions of soil microbial biomass, and whether this changes are correlated to soil organic matter contents.

\section{Material and Methods}

\section{Experimental sites}

Soil samples were collected in twelve sites in the municipalities of Colombo, Rio Branco do Sul, Itaperuçu and Campo Magro in the Metropolitan Region of Curitiba, South Brazil (Tables 1 and 2), between September and November 2016. The region is characterized by altitudes varying between 730 and $1026 \mathrm{~m}$, subtropical humid climate - Cfb according to Köppen-Geiger climate classification, mean annual temperatures lower than $21^{\circ} \mathrm{C}$, thermal amplitude between $9{ }^{\circ} \mathrm{C}$ and $23^{\circ} \mathrm{C}$, total annual precipitation between 1,300 and 1,800 $\mathrm{mm}$ and well distributed rains throughout the year. The bedrock in the area is mostly clayey and the soils are poorly developed (known as Cambissolos in the Brazilian Soil Classification System (SANTOS et al., 2018; and as Inceptisols in the USDA Soil Taxonomy). All sites were located within small farms that produce and market vegetables throughout the year. Soil samples were collected from side-by-side horticultural and fragments of native secondary forest areas having soils with similar origin, at the same topographic level and the same position in relation to the sunshine.

Table 1. Sample sites in the Metropolitan Region of Curitiba*.

\begin{tabular}{|c|c|c|c|c|}
\hline Site & $\begin{array}{l}\text { Altitude } \\
\text { (m) }\end{array}$ & Coordinates & $\begin{array}{c}\text { Fertilizer } \\
\text { (mineral N-P-K plus...) }\end{array}$ & Relief \\
\hline 1 & 703 & $25^{\circ} 05^{\prime} 10.19^{\prime \prime} \mathrm{S} ; 49^{\circ} 34^{\prime} 72^{\prime \prime} \mathrm{W}$ & stove ash & Wavy \\
\hline 2 & 641 & $25^{\circ} 4^{\prime} 34.46^{\prime \prime} \mathrm{S} ; 49^{\circ} 34^{\prime} 34.93^{\prime \prime} \mathrm{W}$ & no one & Wavy \\
\hline 3 & 1001 & $25^{\circ} 15^{\prime} 0.11^{\prime \prime S} ; 49^{\circ} 12^{\prime} 55.64^{\prime \prime W}$ & no one & Wavy \\
\hline 4 & 880 & $25^{\circ} 17^{\prime} 49.23^{\prime \prime} \mathrm{S} ; 49^{\circ} 26^{\prime} 8.10^{\prime \prime} \mathrm{W}$ & poutry litter & Wavy \\
\hline 5 & 782 & $25^{\circ} 16^{\prime} 26.65^{\prime \prime S} ; 49^{\circ} 27^{\prime} 41.40^{\prime \prime} \mathrm{W}$ & poutry litter & Wavy \\
\hline 6 & 787 & $25^{\circ} 16^{\prime} 25.86^{\prime \prime} \mathrm{S} ; 49^{\circ} 27^{\prime} 40.43^{\prime \prime} \mathrm{W}$ & poutry litter & Soft Wavy \\
\hline 7 & 980 & $25^{\circ} 13^{\prime} 23.78^{\prime \prime S} ; 49^{\circ} 14^{\prime} 29.09^{\prime \prime W}$ & poutry litter & Soft Wavy \\
\hline 8 & 1026 & $25^{\circ} 14^{\prime} 44.94^{\prime \prime} \mathrm{S} ; 49^{\circ} 13^{\prime} 36.62^{\prime \prime W}$ & poutry litter & Wavy \\
\hline 9 & 972 & $25^{\circ} 13^{\prime} 38.43^{\prime \prime S} ; 49^{\circ} 14^{\prime} 19.19^{\prime \prime W}$ & poutry litter & Wavy \\
\hline 10 & 1020 & $5^{\circ} 14^{\prime} 43.65^{\prime \prime S} ; 49^{\circ} 13^{\prime} 30.96 " \mathrm{~W}$ & poutry litter + soluble fertilizer & Wavy \\
\hline 11 & 1019 & $25^{\circ} 14^{\prime} 6.04^{\prime \prime}$; $49^{\circ} 14^{\prime} 24.38^{\prime \prime W}$ & poutry litter + soluble fertilizer & Wavy \\
\hline 12 & 1007 & $25^{\circ} 14^{\prime} 6.32^{\prime \prime S} ; 49^{\circ} 14^{\prime} 41.80^{\prime \prime} \mathrm{W}$ & poutry litter + soluble fertilizer & Soft Wavy \\
\hline
\end{tabular}

* Soils were classified as Cambisol by the Brazilian System of Soil Taxonomy (Santos et al. 2018). Forest native vegetation were classified as Mixed Ombrophilous Forest under secondary formation. Traditionally, farmers allow bovine cattle to graze lower vegetation inside the forest fragments. The horticultural systems included rotation of short-cycle vegetables (cabagge, lettuce, carrot, radish, tomato, etc.) in rotation during the year. Farmers apply N-P-K fertilizers and occasionally other source of nutrients, but not with a fixed calendar. Therefore, readers are asked to use Table 2 to know the levels of soil fertility during the study. 
Table 2. Soil chemical attributes and clay contents in horticultural and native areas of the Metropolitan Region of Curitiba.

\begin{tabular}{|c|c|c|c|c|c|c|c|c|c|c|c|c|c|c|c|}
\hline \multirow{2}{*}{ Site } & \multirow{2}{*}{$\begin{array}{l}\text { pH } \\
\text { NAT HORT }\end{array}$} & \multirow{2}{*}{$\begin{array}{l}\mathbf{A l}^{3+} \\
\text { NAT }\end{array}$} & \multirow[b]{2}{*}{ HORT } & \multirow{2}{*}{$\begin{array}{l}\mathbf{H}+\mathbf{A l} \\
\mathrm{NAT}\end{array}$} & \multirow[b]{2}{*}{ HORT } & \multirow{2}{*}{$\begin{array}{l}\mathrm{Ca}^{2+} \\
\text { NAT }\end{array}$} & \multirow[b]{2}{*}{ HORT } & \multirow{2}{*}{$\begin{array}{l}\mathrm{Mg}^{2+} \\
\text { NAT }\end{array}$} & \multirow[b]{2}{*}{ HORT } & \multirow{2}{*}{$\begin{array}{l}\mathbf{K}^{+} \\
\text {NAT }\end{array}$} & \multirow[b]{2}{*}{ HORT } & \multirow{2}{*}{$\begin{array}{l}\text { Clay } \\
\text { NAT } \\
\end{array}$} & \multirow[b]{2}{*}{ HORT } & \multicolumn{2}{|l|}{ Sand } \\
\hline & & & & & & & & & & & & & & NAT & HORT \\
\hline & $---\mathrm{CaCl}_{2}-$ & & - & 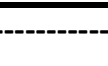 & . & . & . & $m^{-3}$ & & & & 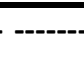 & 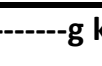 & 1 & \\
\hline & -- & & -- & & & & & & & & & ---- & & & \\
\hline 1 & 3.665 .51 & 3.54 & 0.04 & 16.13 & 3.90 & 0.73 & 4.23 & 0.69 & 1.90 & 0.13 & 0.27 & 533 & 400 & 263 & 421 \\
\hline 2 & 5.735 .41 & 0.03 & 0.04 & 4.20 & 4.77 & 7.77 & 8.46 & 2.28 & 2.90 & 0.62 & 0.32 & 342 & 371 & 417 & 413 \\
\hline 3 & 5.146 .31 & 1.28 & 0.01 & 6.90 & 3.53 & 5.60 & 9.40 & 4.30 & 4.03 & 0.20 & 0.98 & 467 & 417 & 283 & 292 \\
\hline 4 & 4.535 .81 & 0.17 & 0.00 & 8.20 & 3.73 & 2.83 & 5.18 & 1.79 & 2.61 & 0.10 & 0.47 & 313 & 238 & 225 & 121 \\
\hline 5 & 5.365 .83 & 0.02 & 0.14 & 5.20 & 4.17 & 5.53 & 5.92 & 3.47 & 2.97 & 0.29 & 1.40 & 375 & 404 & 354 & 308 \\
\hline 6 & 5.326 .34 & 0.03 & 0.00 & 5.00 & 3.13 & 3.59 & 5.58 & 3.22 & 3.25 & 0.19 & 1.14 & 275 & 329 & 138 & 129 \\
\hline 7 & 4.355 .20 & 0.54 & 0.06 & 9.67 & 5.83 & 3.27 & 6.51 & 1.30 & 2.26 & 0.08 & 0.13 & 454 & 454 & 225 & 204 \\
\hline 8 & 4.405 .43 & 0.62 & 0.29 & 9.57 & 4.73 & 2.39 & 3.43 & 1.49 & 1.13 & 0.17 & 0.51 & 475 & 413 & 238 & 171 \\
\hline 9 & 4.966 .19 & 0.03 & 0.00 & 5.53 & 3.10 & 4.02 & 4.35 & 2.02 & 2.31 & 0.28 & 0.89 & 283 & 383 & 275 & 183 \\
\hline 10 & 5.176 .04 & 0.29 & 0.02 & 8.23 & 3.03 & 5.52 & 4.11 & 3.58 & 2.65 & 1.04 & 1.40 & 396 & 354 & 308 & 542 \\
\hline 11 & 5.956 .01 & 0.00 & 0.02 & 4.13 & 4.13 & 8.22 & 5.76 & 3.73 & 3.47 & 0.50 & 0.49 & 458 & 542 & 200 & 196 \\
\hline 12 & 6.056 .22 & 0.00 & 0.00 & 4.00 & 3.63 & 6.80 & 7.12 & 3.77 & 3.48 & 0.23 & 1.66 & 383 & 367 & 142 & 133 \\
\hline $\begin{array}{l}\text { Averag } \\
\text { e }\end{array}$ & 6 & 0.55 & 0.05 & 7.23 & 3.98 & 4.69 & 5.84 & 2.64 & 2.75 & 0.32 & 0.80 & 349 & 352 & 397 & 389 \\
\hline
\end{tabular}

* Mean of three samples.

\section{Soil samples}

Three composite soil samples were collected at $0-20 \mathrm{~cm}$ depth and packed in polyethylene bags. The samples were divided into two subsamples. The first one was cleaned from fragments of plants and remains of soil fauna, sieved in a $2 \mathrm{~mm}$-mesh and stored at $4{ }^{\circ} \mathrm{C}$ for microbiological analyses done before a period of 50 days under storage. The second subsample was oven dried at $40{ }^{\circ} \mathrm{C}$ until constant weight and submitted to chemical and physical analyses.

\section{Physical and chemical analyses}

Soil particle size was determined with the Bouyoucos densimeter method (GEE; BAUDER, 1986). Soils chemical analyses were performed according to the methods of Soil Survey Laboratory Staff (USDA-NRCS, 1996), by extracting exchangeable $\mathrm{Ca}^{+2}, \mathrm{Mg}^{+2}$ and $\mathrm{Al}^{+3}$ with $1 \mathrm{~mol} \mathrm{~L}^{-1} \mathrm{KCl}$, exchangeable $\mathrm{K}^{+}$with Mehlich-I solution, and measuring soil $\mathrm{pH}$ in $0.01 \mathrm{~mol} \mathrm{~L}^{-1} \mathrm{CaCl}_{2}$. Total nitrogen (TN) and total organic carbon (TOC) were determined by dry combustion in elemental analyzer (CHNOS), model Vario El III - elementar ${ }^{\circledR}$, Germany.

\section{Carbon and Nitrogen of the Microbial Biomass ( $M B C$ and $\mathrm{MBN}$ )}

Carbon and nitrogen of the microbial biomass were measured using the fumigationextraction method modified by Vance et al. (1987) and Brookes et al. (1985). Analyses were performed using two soil subsamples. The first subsamples (20 g moist soil) were placed in vials into a hermetically sealed A36 carbon steel box, containing other three $50 \mathrm{~mL}$ vials containing water (non-fumigated soil) and another three 50 $\mathrm{mL}$ vials containing ethanol-free chloroform for fumigation, and, then submitted to vacuum (600 $\mathrm{mmHg}$ ) for 24 hours. After incubation, chloroform was removed from soil by intermittent vacuum, for 3 minutes, 5 times. The second subsample $(20 \mathrm{~g}$ moist soil) was let to rest in the dark for extraction. The soil was added to $50 \mathrm{~mL}$ of potassium sulfate solution $\left(0.5 \mathrm{M} \mathrm{K}_{2} \mathrm{SO}_{4}\right)$, shaken for 60 minutes in an orbital shaker, centrifuged at 2,500 rpm for 10 minutes and finally filtered. The supernatant corresponding to intracellular material was stored at $-20^{\circ} \mathrm{C}$ until analysis, not exceeding 30 days.

The extract $C$ was determined according to Bartlett and Ross (1988) using a spectrophotometer (Shimadzu UVmini-1240 Inc, Kyoto, Japan) with wavelength of $495 \mathrm{~nm}$. The $M B C$ was calculated by the difference between fumigated and non-fumigated samples (mg C kg soil), using a $k_{c}$ correction factor of 0.41 (ANDERSON; DOMSCH, 1978).

Nitrogen was determined after digestion with concentrated $\mathrm{H}_{2} \mathrm{SO}_{4}$ at $350{ }^{\circ} \mathrm{C}$ (Bremner, 1965). Ammoniacal $\mathrm{N}\left(\mathrm{N}-\mathrm{NH}_{4}\right)$ was obtained by colorimetry with indophenol blue, according to Feije and Anger (1972). Absorbances were measured in spectrophotometer (Shimadzu UVmini-1240 Inc, Kyoto, Japan) with a wavelength of $630 \mathrm{~nm}$. Microbial biomass N (MBN) was 
calculated like $\mathrm{MBC}$, but using a $\mathrm{k}_{\mathrm{N}}$ correction factor of 0.54 (BROOKES et al., 1985).

\section{$P$ in the Microbial Biomass (MBP)}

The MBP was obtained by fumigationextraction method (BROOKES et al., 1982), modified by Vance et al. (1987), using two samples of $10 \mathrm{~g}$ moist soil. Fumigation was done as described for $M B C$, but extraction of $P$ was performed with sodium bicarbonate $(0.5 \mathrm{M}$ $\mathrm{NaHCO}_{3}$ ). After extraction, $20 \mathrm{~mL}$ aliquots of the extracts were transferred to digestion tubes, amended with $2 \mathrm{~mL}$ perchloric acid and $1 \mathrm{~mL}$ of $\mathrm{MgC}_{2}$ and then boiled until they were colorless. The digested extract $\mathrm{P}$ was obtained by blue molybdate method (MURPHY; RILEY, 1962), using a wavelength of $660 \mathrm{~nm}$. MBP was calculated like $M B C$, but using a $k_{p}$ correction factor of 0.40 (ANDERSON; DOMSCH, 1978).

\section{P solubilizing bacteria (PSB)}

Fresh soil samples of each experimental unit were submitted to serial dilution with $\mathrm{NaCl}$ $0.85 \%$ (up to $10^{-4}$ ). The diluted samples were then spread on three Petri dishes with dextrose-yeast medium containing unsoluble phosphate (KATZNELSON; BOSE, 1959) to count the number of colony-forming unit (CFU) of total bacteria and $P$ solubilizing bacteria (PSB). Petri dishes were incubated by inversion at $25{ }^{\circ} \mathrm{C}$ for 12 days. Colonies forming a transparent halo around their central axis were counted for PSB.

\section{Soil Total $\mathbf{P}$, inorganic $\mathbf{P}$, organic $\mathbf{P}$ and available $\mathbf{P}$ Soil phosphate $(P)$ fractions were} determined in different extracts obtained from the same soil sample. Total P (TP) and inorganic P (iP) were obtained from $2 \mathrm{~g}$ moist soil, corrected to dry weight, according to Olsen and Sommers (1982). TP extracts were obtained from $2 \mathrm{~g}$ of dry soil samples $\left(45^{\circ} \mathrm{C}\right.$ in oven for $24 \mathrm{~h}$ ) placed in porcelain crucibles, heated in a muffle at $550{ }^{\circ} \mathrm{C}$ for 1 hour, and resuspended in $50 \mathrm{~mL} \mathrm{H}_{2} \mathrm{SO}_{4} 0.5 \mathrm{~mol} \mathrm{~L}^{-1}$. The iP extracts were obtained from non-heated soil samples placed in glass jars, suspended in $50 \mathrm{~mL}$ $\mathrm{H}_{2} \mathrm{SO}_{4} 0.5 \mathrm{~mol} \mathrm{~L}^{-1}$ and shaked in horizontal stirrer at $220 \mathrm{rpm}$ for 16 hours. In both determinations (TP and iP), soil extracts were filtered through quantitative paper filter (nominal retention of 2 micra). P content in each extract was determined in an inductively coupled plasma optical emission spectrometer (ICP-OES VARIAN 720-ES). Organic P
(oP) was estimated after ignition (Olsen and Sommers, 1982) from the difference between TP and iP. Available $\mathrm{P}$ (aP) was extracted with Mehlich-I solution $\left(\mathrm{H}_{2} \mathrm{SO}_{4} 0.0125 \mathrm{~mol} \mathrm{~L}^{-1}+\mathrm{HCl} 0.05\right.$ $\mathrm{mol} \mathrm{L}^{-1}$ ).

\section{Experimental design and statistical analysis}

Records of MBC, MBN, MBP, number of PSB colony-forming units and soil chemical attributes were submitted to Shapiro Wilk test to confirm ANOVA assumptions. ANOVA was performed in a completely randomized experimental design, in which, the two treatments (native versus horticultural areas) were represented by 12 (sites) times 3 (replicates) independent samples. Pearson correlations were generated within each treatment, with 95\% confidence interval. Statistical analyses were performed using the $\mathrm{R}$ environment (RSTUDIO TEAM, 2016) and Microsoft Excel 2010.

\section{Results}

The conversion of native areas into horticultural fields modified the soil chemical and biological attributes and altered biogeochemical cycling processes. Analyses of soil total and fractional contents $\mathrm{C}, \mathrm{N}$ and $\mathrm{P}$ evidenced that horticultural systems altered the fractions and the ratios of these nutrients in relation to native forest areas (Table 3). The correlations between variables (Table 4) indicate that the modified soil C, N and P fractions in horticultural areas probably caused alterations in the microorganisms functioning on the $\mathrm{P}$ biogeochemical cycle.

\section{Carbon and Nitrogen soil fractions}

Soils in the horticultural areas lost an average of $38 \%$ of the organic carbon (TOC) compared to native areas (Table 3), with few differences in trends among the 12 sampling sites (data not shown). The low TOC values followed the low values of total nitrogen (TN) so that, horticultural areas contained $31 \%$ less TN than native areas. The soils of the horticultural areas had a lower $\mathrm{C} / \mathrm{N}$ ratio (8\%) than the native areas (Table 3 ), in spite of positive correlations of TOC with TN increases. The MBP content was not related to the TOC content, $\mathrm{TN}$ and $\mathrm{C} / \mathrm{N}$ ratio (Table 4). 
Table 3. Soil biological attributes, soil $P$ fractions and soil chemistry ratios in native and horticultural areas of the Metropolitan Region of Curitiba.

\begin{tabular}{|c|c|c|c|c|c|c|}
\hline Biological attributes & Unities & NAT & $\begin{array}{c}\text { CV(\%) } \\
\text { NAT }\end{array}$ & HORT & $\begin{array}{l}\text { CV(\%) } \\
\text { HORT }\end{array}$ & $\begin{array}{l}\text { Index of } \\
\text { Change (\%) }\end{array}$ \\
\hline TOC (Total Organic Carbon) & $\mathrm{gC} \mathrm{kg}^{-1}$ soil & $45.92 \mathrm{a}$ & 27.5 & $28.57 \mathrm{~b}$ & 42.8 & -23.3 \\
\hline TN (Total Nitrogen) & $\mathrm{g} \mathrm{N} \mathrm{kg}^{-1}$ soil & $3.92 \mathrm{a}$ & 106.1 & $2.67 \mathrm{~b}$ & 65.3 & -19.0 \\
\hline C/N (Soil C/N Ratio) & $\%$ & $11.43 \mathrm{a}$ & 79.4 & $10.43 a$ & 78.2 & -4.6 \\
\hline MBC (Microbial Biomass-C) & $\mathrm{mg} \mathrm{C} \mathrm{kg}{ }^{-1}$ soil & 325.18 a & 29.6 & $222.81 b$ & 46.4 & -18.7 \\
\hline MBN (Microbial Biomass-N) & $\mathrm{mg} \mathrm{N} \mathrm{kg}^{-1}$ soil & $96.22 \mathrm{a}$ & 69.9 & $62.54 \mathrm{~b}$ & 54.5 & -21.2 \\
\hline MBP (Microbial Biomass-P) & $\mathrm{mg} \mathrm{P} \mathrm{kg}^{-1}$ soil & $38.88 \mathrm{a}$ & 6.4 & $61.11 \mathrm{a}$ & 13.5 & 22.2 \\
\hline qMic (Microbial quotient) & $\%$ & $0.76 a$ & 32.4 & $0.85 \mathrm{a}$ & 20.0 & 5.6 \\
\hline ТВ (Total bacteria) & CFU $100 \mathrm{~g}^{-1}$ soil & $11141.67 \mathrm{a}$ & 158.0 & $11807.41 \mathrm{a}$ & 178.0 & 2.9 \\
\hline PSB (P Solubilizing Bacteria) & CFU $100 \mathrm{~g}^{-1}$ soil & $131.94 \mathrm{a}$ & 19.8 & $73.10 \mathrm{~b}$ & 46.2 & -28.7 \\
\hline \multicolumn{7}{|l|}{ Fractions of soil phosphate } \\
\hline TP (total phosphate) & $\mathrm{mg} \mathrm{P} \mathrm{kg}^{-1}$ soil & $388.66 \mathrm{~b}$ & 45.7 & $979.20 \mathrm{a}$ & 46.0 & 43.2 \\
\hline iP (inorganic phosphate) & $\mathrm{mg} \mathrm{P} \mathrm{kg}{ }^{-1}$ soil & $135.80 \mathrm{~b}$ & 45.7 & 709.63 a & 46.0 & 67.9 \\
\hline oP (organic phosphate) & $\mathrm{mg} \mathrm{P} \mathrm{kg}{ }^{-1}$ soil & 252.85 a & 70.6 & 269.57 a & 62.0 & 3.2 \\
\hline aP (available phosphate) & $\mathrm{mg} \mathrm{P} \mathrm{kg}{ }^{-1}$ soil & $15.29 \mathrm{~b}$ & 32.4 & $100.77 \mathrm{a}$ & 20.0 & 73.7 \\
\hline \multicolumn{7}{|l|}{ Soil chemistry ratios } \\
\hline $\mathrm{iP} / \mathrm{TP}$ & unitless & $0.349 \mathrm{~b}$ & 45.7 & $0.725 \mathrm{a}$ & 46.0 & 35.0 \\
\hline OP/TP & unitless & $0.651 \mathrm{a}$ & 30.9 & $0.275 \mathrm{~b}$ & 24.5 & -40.6 \\
\hline MBP/TP & unitless & $0.100 \mathrm{a}$ & 51.0 & $0.064 \mathrm{a}$ & 64.2 & -22.0 \\
\hline
\end{tabular}

* Means of 36 samples. Index of change $=\{$ (Horticultural-Native)/(Horticultural + Native) $\}{ }^{*} 100$, where "Horticultural" were the means of measurements in horticultural soil samples and "Native" were the means in native forest soil samples. Diferent letters indicate statistical differences at $\mathrm{p}<0.05$ by the $t$-test. n.e. $=$ not estimated. $\mathrm{CV}(\%)=$ coefficient of variation. HORT= horticultural; NAT=native

Table 4. Pearson correlation between soil microbiological attributes and $\mathrm{P}$ fractions or total $\mathrm{C}$, total $\mathrm{N}$ or $\mathrm{C} / \mathrm{N}$ ratios in native and horticultural areas of the Metropolitan Region of Curitiba.

\begin{tabular}{|c|c|c|c|c|c|c|c|c|c|c|c|c|}
\hline & \multicolumn{6}{|c|}{ Native } & \multicolumn{6}{|c|}{ Horticultural } \\
\hline & PSB & TP & aP & TOC & TN & $\mathrm{C} / \mathrm{N}$ & PSB & TP & $\mathrm{aP}$ & TOC & TN & $\mathrm{C} / \mathrm{N}$ \\
\hline MBC & ns & ns & 0.691 & 0.759 & 0.758 & ns & Ns & ns & ns & ns & ns & ns \\
\hline MBN & ns & ns & 0.834 & 0.770 & 0.861 & -0.621 & Ns & ns & ns & 0.614 & 0.611 & ns \\
\hline MBP & ns & ns & ns & ns & ns & ns & 0.647 & ns & ns & ns & ns & ns \\
\hline qMic & 0.638 & ns & 0.831 & -0.702 & -0.658 & ns & 0.563 & ns & ns & -0.588 & -0.562 & ns \\
\hline TB & 0.610 & 0.592 & ns & ns & ns & ns & Ns & ns & ns & ns & ns & ns \\
\hline PSB & --- & ns & ns & ns & ns & ns & --- & ns & ns & ns & ns & ns \\
\hline
\end{tabular}

*Values of coefficient of Pearson with significance $p \leq 0.05$ by the Student test. ns= not significant at $p \leq 0.05$.

\section{Phosphorus soil fractions}

Soil total $P(T P)$ content considers the sum of inorganic $P(i P)$, organic $P$ (oP), which are the not available fractions, and, available $P(a P)$. The analyses in soil samples from Metropolitan Region of Curitiba showed that soil TP fractions were generally larger in horticultural systems than in native areas (Table 3).

It is interesting to note that in horticultural areas, significant increases in TP were accompanied by significant increases in iP (Table 3; Fig. 1) whereas the highest fraction of TP in native areas was related to OP. In the horticultural areas, iP represented $59 \%$ of TP, while oP represented only $32 \%$ (Fig. 1). However, in the native areas, iP represented $28 \%$ of TP and oP represented $69 \%$. 
Figure 1. Percent distribution of soil $P$ fractions in native and horticultural systems of the Metropolitan Region of Curitiba. The patterns were obtained by compiling data from 12 independent sites and 36 soil samples.

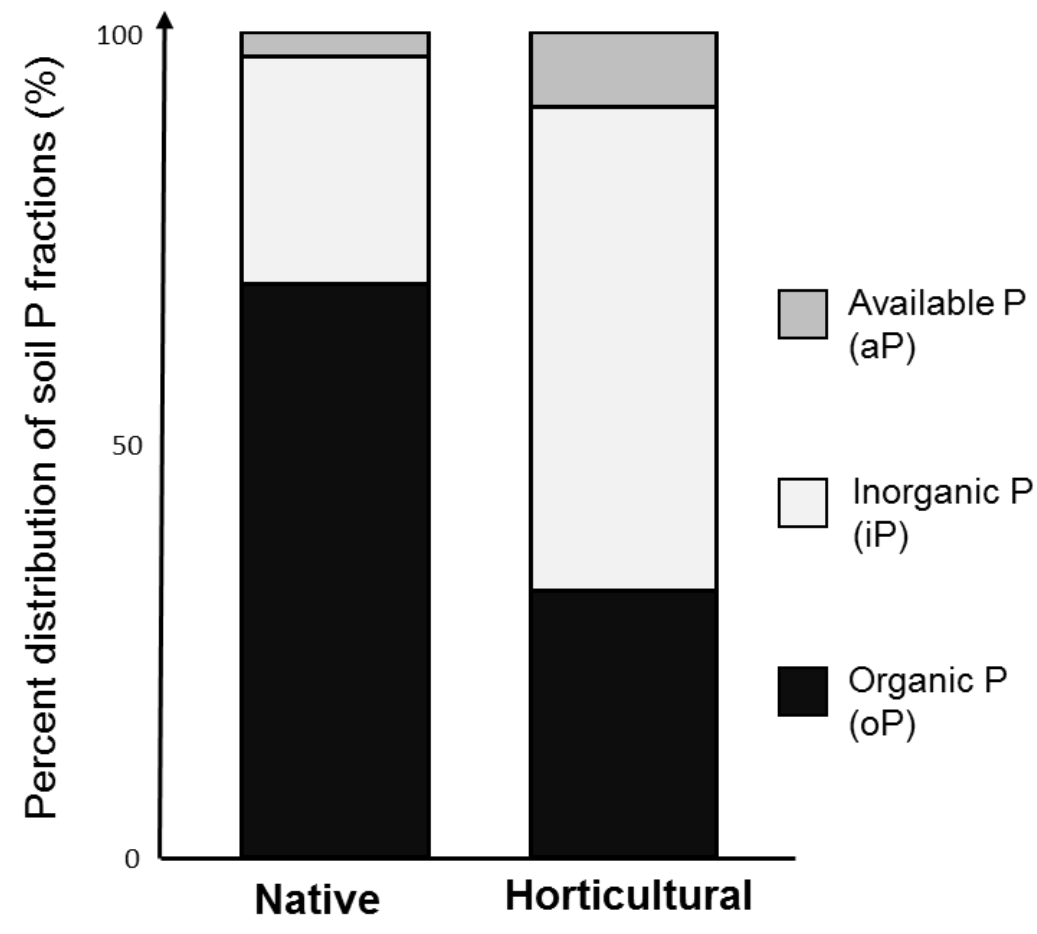

\section{P solubilizing bacteria (PSB) and significant correlations}

The number of total bacteria (TB) did not differ significantly between native and horticultural areas (average of 11,500 CFU $100 \mathrm{~g}^{-1}$ soil; Table 3).

In native areas, TOC and TN were highly correlated with $\mathrm{C} / \mathrm{N}$ ratio, $\mathrm{MBC}$ and $\mathrm{MBN}$. The correlation between TOC and TN was $r=0.965$ ( $p$ $=3.6 \times 10^{-7}$ ); the correlation between TOC and MBC was $r=0.759(p=0.0042)$ and MBN was $r=$ $0.770(p=0.0034)$; the correlation between TN and MBC was $r=0.758(p=0.0043)$ and MBN was $r=0.861(p=0.0003)$. In native areas, TOC $(r=$ $0.599, p=0.0397), M B C(r=0.691, p=0.0128)$ and MBN $(r=0.834, p=0.0007)$ correlated with aP. Additionally, MBC $(r=0.692, p=0.0126)$ and MBN $(r=0.667, p=0.0179)$ correlated with total bacteria (TB). TB showed a positive correlation with TP $(r=0.592 ; p=0.0427)$ and $\mathrm{PP}(r=0.700 ; p$ $=0.0549)$ and with PSB $(r=0.610 ; p=0.0351)$.

An interesting point is that PSB correlated with qMic $(r=0.638 ; p=0.025)$ and with iP ( $r=0.566 ; p=0.054$; Table 4). Furthermore, qMic was negatively correlated with TOC and TN in both native and horticultural areas, suggesting that soil $\mathrm{P}$ fractions play a role in regulating PSB populations, while these PSB regulate the stocks and consumption of TOC and $\mathrm{TN}$ of soils.

\section{Discussion}

Soil chemical and mineralogical characteristics influence the availability of $P$ in soil solution, but most of the available $P$ in soil solution is the result of biogeochemical cycles of $\mathrm{C}$ and $\mathrm{N}$, through the mineralization and immobilization processes by soil microbial biomass (HARTMAN; RICHARDSON, 2013; HEUCK et al., 2015; SPOHN; CHODAK, 2015). Soil microbial biomass is a very sensitive soil attribute to soil changes, being affected by climate, land use, roots density and diversity, soil physical and chemical attributes and, by the availability of organic substrate for growth (KASCHUK et al., 2010; KASCHUK et al., 2011; SARKER et al., 2018; VEZZANI et al., 2018). If organisms with heterotrophic metabolism grew under a homeostatic paradigm, the increases in the $C$ substrate, i.e. the soil TOC, would result in increases in soil $\mathrm{MBC}$ with proportional increases in MBN and MBP (EHLERS et al., 2010; HARTMAN; RICHARDSON, 2013; HEUCK et al., 2015; SPOHN; CHODAK, 2015; Ll et al., 2015; YAO et al., 2018). However, under varying soil nutrient supplies, soil microbial communities may adjust 
their metabolism and composition (EHLERS et al., 2010; HARTMAN; RICHARDSON, 2013; HEUCK et al., 2015; SPOHN; CHODAK, 2015; UJ, 2015; YAO et al., 2018). In this study, the conversion of native into horticultural area decreased soil MBC (microbial biomass-C) by $18 \%$ while it increased MBP (microbial biomass-P) by $22 \%$ (Table 3 ). If the homeostatitc paradigm worked in this situation, the conversion of native areas into horticultural areas would stimulate or depress the nutrients at proportional ratios, increases in $M B C$ and MBN would be associated with increases in MBP. However, it seems that the biogeochemical cycles are interconnected and supply of $P$ fertilizers to native soils may accelerate the degradation of soil organic matter reserves.

Our study revealed two different systems in terms of soil $P$ fractions. Horticultural areas received large amounts of $P$ via fertilization, which increased soil TP in relation to native areas. Other studies showed that $\mathrm{P}$ availability is a determining factor of soil microbial taxonomy and its structure (HARTMAN; RICHARDSON, 2013; MARANGUIT et al., 2017). In this study, increases in soil $P$ fractions of the horticultural areas was not associated with increased MBP (Table 3), but it led to decreases in the number of CFU (colonyforming units) of PSB (P-solubilizing bacteria) (Table 3). The P solubilization mechanisms by PSB may be exsudation of organic acids that decreases the soil $\mathrm{pH}$ and dissociates ferrols and aluminols, and/or exudation of phosphatases that breaks down the organic P (SHARMA et al., 2013; ZHU et al., 2018). The mechanisms of $P$ solubilization may have contributed to changes in the microbial quotient (ratio of MBC to TOC) in both native and horticultural areas (correlation qMic versus PSB; Table 4).

Several studies have shown that agricultural practices may impair the maintenance of soil organic matter due to temperature and humidity oscillations, factors that influence soil microbial activity (KASCHUK et al., 2010; RAMOS et al., 2014). Data in this study suggested that soil practices and probably addition of $P$ may have increased the rates of decomposition of soil organic matter, decreasing the contents of soil TOC, TN and C/N contents (Table 3). Since higher values of $C$ and $N$ in the microbial biomass and higher $\mathrm{C} / \mathrm{N}$ ratio are associated with stability of soil organic matter (SARKER et al., 2018; VEZZANI et al., 2018), the data herein suggested that horticultural areas are also loosening the stability of soil organic matter. In addition, the analyses revealed negative correlations of qMic (ratio of MBC to TOC) with TOC or TN (Table 4). The value of qMic has innumerous times been utilized as indicator of soil organic matter capacity to support soil microbial biomass (INSAM; DOMSCH 1988; KASCHUK et al., 2010; KASCHUK et al., 2011), but it is also possible that microbes in horticultural areas are growing and consuming TOC faster than in native areas due to increased availability of other soil nutrients. In the case, native areas contained more TOC and TN (Table 3) and accumulated larger percentage of oP (Fig. 3) whereas horticultural areas accumulated larger percentage of iP (Fig. 3) within the soil $P$ fractions. These results agree with the fact that $P$ mineralization from soil organic matter can be driven by microbial need for carbon (SPOHN; KUZYAKOV, 2013).

Having intensive agriculture in metropolitan region offers several opportunities for economical growth, but it may also threaten the environment. Therefore, while P limitation is an issue over the world, in metropolitan regions like MRC, excessive $\mathrm{P}$ addition may become a potential environmental issue. Intensive agriculture may result in soil erosion (RAMOS et al., 2014). This study showed that changes in the soil $P$ fractions suggested a shift in the soil community bacterial structure and in the values of soil microbial biomass of the two different soil ecosystems. The excessive $\mathrm{P}$ addition may stimulate soil microbial attack to soil organic matter reserves, which may have consequences for maintenance of soil quality and agriculture sustainability.

\section{Acknowledgments}

The authors aknowledge anonymous reviewers for comments on an early version, Jeferson Dieckow, Vander de Freitas Melo for suggestions in the methodology; Carla Gomes Albuquerque, Denise de Conti, Fabiana Gavelaki, Heila Silva Araújo, Josianne Meyer, Leticia Maduro Gonçalves, Maria Aparecida Carvalho Santos and Marla Cristina Becker Motta by technical assistance; and the Post-Graduate Support Program (PROAP) of Universidade Federal do Paraná, Curitiba, Brazil, for financing this work. T. S. L. and J. P. S. aknowledge the Coordination of Improvement of Higher Education Personnel (CAPES, Brazil), and, C. L. M. aknowledge 
Araucária Foundation, State of Paraná, Brazil, for the scholarships.

\section{References}

ANDERSON, J.P.E.; DOMSCH, K.H. A physiological method for the quantitative measurement of microbial biomass in soils. Soil Biology \& Biochemistry, v.10, p.215-221, 1978. https://doi.org/10.1016/0038-0717(78)90099-8

BALOTA, E.L.; ANDRADE, D.S.; COLOZZI-FILHO, A.; DICK R.P. Microbial biomass in soils under different tillage and crop rotation system. Biology Fertility of Soils, v.38, p.15-20, 2003. https://doi.org/10.1007/s00374-003-0590-9

BARTLETT, R.J.; ROSS, D.N. Colorimetric determination of Biology and Fertility Soils. v. oxidizable carbon in acid soil solutions. Soil Science American Journal, v.52, p.1191-1192, 1988.

https://doi.org/10.2136/sssaj1988.03615995005 200040055x

BREMNER, J.M. Inorganic forms of nitrogen. In: Black CB et al. Methods of soil analysis, p. 11491178. American Society of Agronomy, Madison, 1965.

BROOKES, P.C.; LANDMAN, A.; PRUDENT, G.; JENKINSON, D.SChloroform fumigation and the release of soil nitrogen: $A$ rapid direct estraction method to measure microbial biomass nitrogen in soil. Soil Biology \& Biochemistry, v.17, p.837842, $1985 . \quad$ https://doi.org/10.1016/00380717(85)90144-0

BROOKES, P.C.; POWLSON, D.S.; JENKINSON, D.S. Measurement of microbial biomass phosphorus in soil. Soil Biology \& Biochemistry, v.14, p.319329, 1982. https://doi.org/10.1016/0038$\underline{0717(82) 90001-3}$

EHLERS, K.; BAKKEN, L.R.; FROSTEGÅRD, Å.; FROSSARD, E.; BÜNEMANN, E.K. Phosphorus limitation in a Ferralsol: Impact on microbial activity and cell internal P pools. Soil Biology \& Biochemistry, v.42, p.558-566, 2010. https://doi.org/10.1016/j.soilbio.2009.11.025

FEIJE, F.; ANGER, V. Spot tests in inorganic analyses. Analitical Chimica Acta, v.149, p.363367, 1972.
GEE, G.W.; BAUDER, J.W. Particle-size analysis. In Klute A (ed.) Methods of soil analysis. Part 1. 2nd ed. Agron Monogr 9. ASA and SSSA. Madison. WI, p. 383-411, 1986.

https://doi.org/10.2136/sssabookser5.1.2ed.c15

GERKE, J. Phytate (Inositol Hexakisphosphate) in soil and phosphate acquisition from inositol phosphates by higher plants. A Review. Plant Science Journal, v.4, p.253-266, 2015. https://doi.org/10.3390/plants4020253

GLICK, B.R. Plant growth-promoting bacteria: mechanisms and applications. Hindawi Publishing Corporation. Scientifica, ID 963401, 15 pages.

HARTMAN, W.H.; RICHARDSON, C.J. 2013. Differential nutrient limitation of soil microbial biomass and metabolic quotients $\left(\mathrm{qCO}_{2}\right)$ : Is there a biological stoichiometry of soil microbes? Plos One, v.8, e57127, 2012. https://doi.org/10.1371/journal.pone.0057127

HEUCK, C.; WEIG, A.; SPOHN, M. Soil microbial biomass $\mathrm{C}: \mathrm{N}: \mathrm{P}$ stoichiometry and microbial use of organic phosphorus. Soil Biology \& Biochemistry, v.85, p.119-129, 2015.

https://doi.org/10.1016/j.soilbio.2015.02.029

HOFFLAND, E.; FINDENEGG, G.R.; NELEMANS, J.A. Solubilization of rock phosphate by rape II. Local root exudation of organic acids as a response to P-starvation. Plant and Soil, v.113, p.161-165, 1989. https://doi.org/10.1007/BF02280176

INSAM, H.; DOMSCH, K.H. Relationship between soil organic carbon and microbial biomass on chronosequences of reclamation sites. Microbial Ecology, v.15, p.177-188, 1988. https://doi.org/10.1007/BF02011711

IPARDES. Leituras regionais: mesorregiões geográficas paranaenses: sumário executivo. Instituto Paranaense de Desenvolvimento Econômico e Social. Curitiba: IPARDES, 2004. 34p. Disponível em: http://www.ipardes.gov.br/biblioteca/docs/leitur as_reg_sumario_executivo.pdf. Acesso em: 12 set. 2019.

KAFLE, A.; COPE. K.R.; RATHS, R.; YAKHA, J.K.; SUBRAMANIAN, S.; BÜCKING, H.; GARCIA, K. Harnessing soil microbes to improve plant phosphate efficiency in cropping systems. 
Agronomy, v.9, p.127, 2019. https://doi.org/10.3390/agronomy9030127

KASCHUK, G.; ALBERTON, O.; HUNGRIA, M. Three decades of soil microbial biomass studies in Brazilian ecosystems: Lessons learned about soil quality and indications for improving sustainability. Soil Biology \& Biochemistry, v.42, p.1-13, 2010. https://doi.org/10.1016/j.soilbio.2009.08.020

KASCHUK, G.; ALBERTON, O.; HUNGRIA, M. Quantifying effects of different agricultural land uses on soil microbial biomass and activity in Brazilian biomes: inferences to improve soil quality. Plant and Soil, v.338, p.467-481, 2011. https://doi.org/10.1007/s11104-010-0559-z

KATZNELSON, H.; BOSE, B. Metabolic activity and phosphate-dissolving capability by of bacterial isolates from wheat roots, rhizosphere and non rizosphere soil. Canadian Journal of $\begin{array}{llll}\text { Microbiology, } & \text { v.5, } & \text { p.79-85, } & 1959 .\end{array}$ https://doi.org/10.1139/m59-010

LI, J.; LI, Z.; WANG, F.; ZOU, B.; CHEN, Y.; ZHAO, J.; MO, Q.; LI, Y.; LI, X.; XIA, H. Effects of nitrogen and phosphorus addition on soil microbial community in a secondary tropical forest of China. Biology and Fertility Soils, v.51, p.207-215, 2015. https://doi.org/10.1007/s00374-014-0964$\underline{1}$

MARANGUIT, D.; GUILLAUME, T.; KUZYAKOV, Y. Land-use change affects phosphorus fractions in highly weathered tropical soils. Catena, v.149, p.385-393, 2017. https://doi.org/10.1016/i.catena.2016.10.010

MURPHY, J.; RILEY, J.P. A modified single solution method for the determination of phosphate in natural waters. Analytical Chimica Acta, v.27, p.31-36, 1962. https://doi.org/10.1016/S00032670(00)88444-5

NIU, Y.F.; CHAI, R.S.; JIN, G.L.; WANG, H.; TANG, C.X.; ZHANG, Y.S. Responses of root architecture development to low phosphorus availability: a review. Annals of Botany, v.112, p.391-408, 2013. https://doi.org/10.1093/aob/mcs285

OLSEN, S.R.; SOMMERS, L.E. Phosphorus. In: Page, A.L., Miller, R.H., Keeney, Q.R. (Eds.) Methods of soil analysis. Chemical and microbiological properties. Madison: SSSA, 1982. p.403-430.

https://doi.org/10.2134/agronmonogr9.2.2ed.c2 $\underline{4}$

RAMOS, M.R.; FAVARETTO, N.; DIECKOW, J.; DEDECK. R.A.; VEZZANI, F.M.; ALMEIDA, L.; SPERRIN, M. Soil, water and nutrient loss under conventional and organic vegetable production managed in small farms versus forest system. Journal of Agronomy Rural Development in the Tropics, v.115, p.31-40, 2014.

RICHARDSON, A.E. Prospects for using soil microorganisms to improve the acquisition of phosphorus by plants. Australian Journal of Plant Physiology, v.28, p.897-906, 2001. https://doi.org/10.1071/PP01093

RICHARDSON, A.E.; SIMPSON, R.J. Soil microrganisms mediating phosphosrus availability. Plant Physiology, v.156, p.989-996, 2011. https://doi.org/10.1104/pp.111.175448

RStudio Team. RStudio: Integrated Development for R. RStudio. Boston, MA. 2016. Disponível em: http://www.rstudio.com/

SANTOS, H.G.; JACOMINE, P.K.T.; ANJOS, L.H.C.; OLIVEIRA, V.A.; LUMBRERAS, J.F.; COELHO, M.R.; ALMEIDA, J.A.; ARAÚJO-FILHO, J.C.; OLIVEIRA, J.B.; CUNHA, T.J.F. Sistema Brasileiro de Classificação de Solos. Brasília: Embrapa, 2018.

SARKER, J.R.; SINGH, B.P.; DOUGHERTY, W.J.; FANG, Y.; BADGERYC, W.; HOYLE, F.C.; DALAL, R.C.; COWIE, A.L. Impact of agricultural management practices on the nutrient supply potential of soil organic matter under long-term farming systems. Soil Tillage Research, v. 175, p. 71-81, 2018.

https://doi.org/10.1016/j.still.2017.08.005

SEAB. Valor bruto da produção rural paranaense. Curitiba: SEAB/DERAL, 2016. Disponível em: http://www.agricultura.pr.gov.br/modules/conte udo/conteudo.php?conteudo=156. Acesso em: 12 set. 2019.

SHARMA, S.B.; SAYYED, R.Z.; TRIVEDI, M.H.; GOBI, T.A. Phosphate solubilizing microbes: sustainable approach for managing phosphorus deficiency in agricultural soils. Springer Plus, n.2, p.587, 2013. https://doi.org/10.1186/2193-1801-2-587 
SMITH, S.E.; JAKOBSEN, I.; GRØNLUND, M.; SMITH, F.A. Roles of arbuscular mycorrhizas in plant phosphorus nutrition: Interactions between pathways of phosphorus uptake in arbuscular mycorrhizal roots have important implications for understanding and manipulating plant phosphorus acquisition. Plant Physiology, v.156, p.1050-1057, 2011. https://doi.org/10.1104/pp.111.174581

SPOHN, M.; CHODAK, M. Microbial respiration per unit biomass increases with carbon-tonutrient ratios in forest soils. Soil Biology \& Biochemistry, v.81, p.128-133, 2015. https://doi.org/10.1016/i.soilbio.2014.11.008

SPOHN, M.;KUZYAKOV, Y. Phosphorus mineralization can be driven by microbial need for carbon. Soil Biology \& Biochemistry, v.61, p.69-75, 2013. https://doi.org/10.1016/j.soilbio.2013.02.013

USDA-NRCS. Soil survey laboratory methods manual. Washington, DC: United States Department of Agriculture, 1996. 693p. (Soil Survey Investigations Report; no 42, Version 3)

VANCE, E.D.; BROOKES, P.C.; JENKINSON, D.S. An extraction method for measuring soil microbial biomass C. Soil Biology \& Biochemistry, v.19, p.703-707, 1987. https://doi.org/10.1016/00380717(87)90052-6

VEZZANI, F.M.; GRAIG, A.; MEENKEN, E.; GILLESPIE, R.; PETERSON, M.; BEARE, M.H. The importance of plants to development and maintenance of soil structure, microbial communities and ecosystem functions. Soil Tillage Research, v.175, p.139-149. 2018. https://doi.org/10.1016/j.still.2017.09.002

YAO, Q.; LI, Z.; SONG, Y.; WRIGHT, S.J.; GUO, X.; TRINGE, S.G.; TFAILY, M.M.; PAŠA-TOLIĆ, L.; HAZEN, T.C.; TURNER, B.L.; MAYES, M.A.; PAN, C. Community proteogenomics reveals the systemic impact of phosphorus availability on microbial functions in tropical soil. Nature Ecology Evolution, v.3, p.499-509. 2018. https://doi.org/10.1038/s41559-017-0463-5

YUN, S.J.; KAEPPLER, S.M. Induction of maize acid phosphatase activities under phosphorus starvation. Plant and Soil, v.237, p.109-115. 2001. https://doi.org/10.1023/A:1013329430212

ZHU, J.; LI, M.; WHELAN, M. Phosphorus activators contribute to legacy phosphorus availability in agricultural soils: A review. Journal of Science Total Environment, v.612, p.522-537. 2018.

https://doi.org/10.1016/j.scitotenv.2017.08.095 